\section{Genetic variation analysis of superior cotton varieties of Gossypium hirsutum through microsatellite markers}

\author{
Dede Nuraida, ${ }^{1}$ Yusuf Abdurrajak, ${ }^{2}$ \\ Moh. Amin, ${ }^{2}$ Utami S. Hastutik ${ }^{2}$ \\ ${ }^{1}$ University of PGRI Ronggolawe, \\ Tuban, ${ }^{2}$ State University of Malang, \\ East Java, Indonesia
}

\begin{abstract}
This study was conducted in order to obtain information on genetic variation in populations rated as superior cotton (Gossypium hirsutum L.) varieties in Balittas Malang, Indonesia. The samples used 10 varieties of cotton Kanesia series and 2 other superior varieties that are LRA 5166 and ISA 205A. Indicators of genetic diversity are the number of alleles per locus, allele frequencies, and heterozygosity values. DNA was isolated from the leaves of 3week-old seedlings using the CTAB method. Amplification was performed using 5 SSRs primer pairs of the JESPR series. The results showed five microsatellite loci, yielding 12 alleles with a size range of $80-500 \mathrm{bp}$, with an average number of alleles per locus of 4.60. The average values of heterozygosity of the five loci was high, at 0.71 . Based on the number of alleles, allele frequencies and heterozygosity values, the genetic variation sampled in the superior cotton varieties studied here is quite high.
\end{abstract}

\section{Introduction}

Cotton fiber from the cotton plant (Gossypium hirsutum L.) is the raw material of the textile industry. Approximately 49\% of world demand for fiber is fulfilled by cotton, the remainder of synthetic fibers (34$38 \%$ ), rayon $(8-10 \%)$, and wool $(4-6 \%){ }^{1}$ Requirements for cotton fiber in Indonesia reached 365,000-00,000 tons per year, yet domestic cotton production is only about 2,000 tons per year, $0.4 \%$ of the national cotton demand. ${ }^{1}$ Thus, the remaining demand is derived from imports. ${ }^{2,3}$

So far, cotton breeding programs in Indonesia are conventional, i.e., by selection or crossing based on the superior properties that can be observed through morphological markers. However, in the national cotton development program at this time, the threat of rapid genetic degradation occurring in the varieties used is very real, resulting in decreased levels of productivity, so that a program to more rapidly improve cotton varieties should be commenced. ${ }^{4}$ Information on the available genetic diversity is needed in the breeding process. Genetic diversity can be analyzed based on morphological and molecular markers; however, due to the many shortcomings of morphological markers, in recent years' molecular markers such as microsatellites have become more and more widely used.

Microsatellites are some molecular genetic markers based on short DNA sequences with repeating units consisting of one to six nucleotides. Microsatellite markers have used in many areas of molecular genetics, because of their reproducibility, multi-allelic nature, co-dominant inheritance, relative abundance and good genomic coverage. ${ }^{5}$ Since microsatellite markers are co-dominant, they can detect both homozygous and heterozygous individuals. This study aims to analyze the genetic variation in 12 varieties of cotton that have shown superior performance in Balittas Malang by using microsatellite markers. The parameters obtained included the frequency of allele and heterozygosity values.

\section{Materials and Methods \\ DNA extraction}

The sample consisted of 10 superior varieties of cotton Kanesia series, Kanesia $4,6,7,8,10,11,12,13,14,15$, and 2 other superior varieties (LRA 5166, ISA 205A). DNA was obtained from young leaves taken from 3-week-old seedlings. Isolation of DNA was done using the CTAB method. ${ }^{6-8}$ The quality of DNA was observed in a gel doc system after electrophoresis on a $0.8 \%$ agarose gel stained with ethidium bromide. ${ }^{9-11}$

\section{DNA amplification}

DNA amplification was performed using 5 SSR primer pairs of series JESPR (247, 280, 292, 299, and 303). Amplification reactions were carried out in a total volume of $21 \mu \mathrm{L}$, consisting of $2 \mu \mathrm{L}$ template DNA and $4 \mu \mathrm{L}$ primers (forward and reverse, $2 \mu \mathrm{L}$ each), $12 \mu \mathrm{L}$ PCR mix, and $3 \mu \mathrm{L} \mathrm{dH}_{2} \mathrm{O}$. Amplification was performed using an initial denaturation step at $94^{\circ} \mathrm{C}$ for $5 \mathrm{~min}$, followed by 35 cycles of denaturation at $94^{\circ} \mathrm{C}$ for 30 seconds, annealing at $50^{\circ} \mathrm{C}$ for 30 seconds for primer JESPR 247, and temperature of $48^{\circ} \mathrm{C}$ for the four other primers, each for 30 seconds, and elongation stages at a temperature of $72^{\circ} \mathrm{C}$ for 1 minute. The last cycle was followed by a final elongation at $72^{\circ} \mathrm{C}$ for $10 \mathrm{~min}$ -
Correspondence: Dede Nuraida, University of PGRI Ronggolawe, Jalan Manunggal No. 61, Gedongombo, Semanding, Gedongombo, Semanding, Kabupaten Tuban, Jawa Timur 3523120, Indonesia

E-mail: dede.nuraida@gmail.com

Key words: cotton superior, genetic variation, allele, heterozygosity.

Acknowledgments: the Author thank Balittas Malang, Indonesia to facilitate this study.

Contributions: the author contributed equally

Conflict of interest: the authors declare no potential conflict of interest.

Received for publication: 2 December 2016 Accepted for publication: 1 February 2017.

This work is licensed under a Creative Commons Attribution-NonCommercial 4.0 International License (CC BY-NC 4.0).

CCopyright D. Nuraida et al., 2017

Licensee PAGEPress srl, Italy

International Journal of Plant Biology 2017; 8:6996 doi:10.4081/pb.2017.6996

utes. Amplification products were separated by electrophoresis on a $10 \%$ polyacrylamide gel, and the gel was stained using silver nitrate staining.

\section{Data analysis}

The genetic diversity of each microsatellite locus was obtained by calculating the frequency of the microsatellite allele and its heterozygosity value. The analysis was performed using GENEPOP version 4.0.10.

\section{Results}

\section{Allele frequencies}

Overall, 12 alleles were derived from all five microsatellite loci, with allele sizes ranging from 80-400 bp (Table 1). Each locus had between 3 and 6 alleles (Table 2).

Table 2 shows that the microsatellite alleles A, B, D, and F, with sizes of 80, 100, 150 , and $200 \mathrm{bp}$, respectively, were the most common alleles observed, each allele coming in 3 of the 5 loci observed. Allele J, with size of $300 \mathrm{bp}$, appeared in two out of the five loci observed; alleles C, G, H, I, K, and $\mathrm{L}$ appeared in only one out of the five loci observed.

The frequency of alleles at each locus varied greatly. At loci 1, 2, and 4, the most frequent allele was allele $\mathrm{A}$, with a frequen- 
Table 1. Types and size of alleles from genomic DNA of 12 sampled superior cotton varieties.

\begin{tabular}{lcccccccccccc} 
Alelle & A & B & C & D & E & F & G & H & I & J & K & L \\
Product size (bp) & 80 & 100 & 120 & 150 & 180 & 200 & 220 & 250 & 280 & 300 & 350 & 400 \\
\hline
\end{tabular}

cy at each locus of $0.50,0.83$, and 0.38 , respectively. At loci 3 and 5, the most frequent alleles were $\mathrm{F}$ and $\mathrm{D}$, at 0.29 , and 0.54 , respectively. The frequency of alleles obtained at each locus can describe the frequency of certain genetic profiles that can indicate the genetic diversity of the gene pool within a population.

\section{Diversity and distribution of geno- types}

The number of alleles obtained showed that genotypic diversity was high as well. Table 3 shows the diversity of genotypes obtained at each locus.

In general, the five microsatellite loci observed resulted in a considerable range of genotypes. JESPR 280 and JESPR 303 each produced three kinds of genotypes, JESPR 247 and JESPR 292 five different genotypes, and JESPR 299 six different genotype. The diversity of these genotypes showed the high genetic diversity of the sampled cotton populations.

\section{Heterozygosity}

The results of this study indicate that the heterozygosity for all loci in the 12 superior cotton varieties is high, ranging from 0.33 to 0.92 , with an average for all loci of 0.71 (Table 4).

The third factor that can cause high heterozygosity values as mentioned above, is very likely to occur in a population of the superior cotton varieties observed in this research. From the results of data analysis, the migration of alleles in this population of 0.16 . To factor crosses, from 12 superior cotton varieties sampled in this study is a cross between $83 \%$ while the rest comes from the introduction, where the introduction is also one way to obtain a genetic variation.

\section{Discussion}

Heterozygosity indicates the number of individuals in a population that have different alleles in one locus. ${ }^{12}$ The heterozygosity value will vary depending on the condition of allele frequencies of each locus; a large number of derived alleles at each locus will lead to a high value of heterozygosity in a population. Heterozygosity val-
Table 2. Allele frequencies at five microsatellite loci of 12 sampled superior cotton varieties.

\begin{tabular}{|c|c|c|c|c|}
\hline No & Locus & Repeat Motive & Alelle & Frequency \\
\hline 1 & JESPR 247 & (CT) 15 & $\begin{array}{l}\text { A } \\
\text { B } \\
\text { D } \\
\text { F }\end{array}$ & $\begin{array}{l}0.50 \\
0.23 \\
0.14 \\
0.14\end{array}$ \\
\hline 2 & JESPR 280 & (GT) 10 & $\begin{array}{l}\text { A } \\
\text { B } \\
\text { J }\end{array}$ & $\begin{array}{l}0.83 \\
0.04 \\
0.13\end{array}$ \\
\hline 3 & JESPR 292 & (CTT) 17 & $\begin{array}{c}\mathrm{F} \\
\mathrm{G} \\
\mathrm{H} \\
\mathrm{I} \\
\mathrm{J} \\
\mathrm{K}\end{array}$ & $\begin{array}{l}0.29 \\
0.17 \\
0.13 \\
0.25 \\
0.08 \\
0.08\end{array}$ \\
\hline 4 & JESPR 299 & $(\mathrm{CAT}) 9$ & $\begin{array}{l}\text { A } \\
\text { B } \\
\text { C } \\
\text { D } \\
\text { E }\end{array}$ & $\begin{array}{l}0.38 \\
0.38 \\
0.17 \\
0.04 \\
0.04\end{array}$ \\
\hline 5 & JESPR 303 & $(\mathrm{CAT}) 6$ & $\begin{array}{l}\mathrm{D} \\
\mathrm{F} \\
\mathrm{J}\end{array}$ & $\begin{array}{l}0.54 \\
0.42 \\
0.04\end{array}$ \\
\hline
\end{tabular}

Table 3. The diversity of microsatellite DNA genotypes in 12 superior cotton varieties.

\begin{tabular}{|c|c|c|c|}
\hline No & Locus & Genotipe & Amount \\
\hline 1 & JESPR 247 & $\begin{array}{l}\mathrm{AA} \\
\mathrm{AB} \\
\mathrm{AD} \\
\mathrm{BF} \\
\mathrm{DF}\end{array}$ & $\begin{array}{l}3 \\
4 \\
1 \\
1 \\
2\end{array}$ \\
\hline 2 & JESPR 280 & $\begin{array}{l}\mathrm{AA} \\
\mathrm{AB} \\
\mathrm{AJ}\end{array}$ & $\begin{array}{l}8 \\
1 \\
3\end{array}$ \\
\hline 3 & JESPR 292 & $\begin{array}{l}\mathrm{FF} \\
\mathrm{FG} \\
\mathrm{GI} \\
\mathrm{HI} \\
\mathrm{JL}\end{array}$ & $\begin{array}{l}3 \\
1 \\
3 \\
3 \\
2\end{array}$ \\
\hline 4 & JESPR 299 & $\begin{array}{l}\mathrm{AA} \\
\mathrm{AB} \\
\mathrm{AC} \\
\mathrm{BC} \\
\mathrm{BD} \\
\mathrm{BE}\end{array}$ & $\begin{array}{l}1 \\
5 \\
2 \\
2 \\
1 \\
1\end{array}$ \\
\hline 5 & JESPR 303 & $\begin{array}{l}\text { DD } \\
\text { DF } \\
\text { FJ }\end{array}$ & $\begin{array}{l}2 \\
9 \\
1\end{array}$ \\
\hline
\end{tabular}


Table 4. The value of heterozygosity at each microsatellite locus in the superior cotton varieties.

\begin{tabular}{lcccccc} 
Locus & JESPR 247 & JESPR 280 & JESPR 292 & JESPR 299 & JESPR 303 & Average \\
Heterozygosity & 0.73 & 0.33 & 0.75 & 0.92 & 0.83 & 0.71 \\
\hline
\end{tabular}

ues are the most accurate way to measure genetic variation and describe the diversity of specific genes in a population.

The high value of heterozygosity is probably due to a high enough population dynamic. ${ }^{13}$ Several factors can cause this, including migration, mutation and crossover.

The high genetic variation is characterized by high values of heterozygosity, allele frequency and genotype diversity at each locus, and will be very favorable for the maintenance of the superior cotton populations themselves. A population that has a low heterozygosity value may be easily threatened with extinction. ${ }^{14}$ A population with a high heterozygosity value has an increased chance of survival. Genetic diversity and the ideal population size is an important factor for the survival of a population or a particular species to be adaptable to environmental changes. High genetic diversity will provide an improved opportunity for plants to adapt to their environment. ${ }^{15,16}$

In addition, genetic diversity is important not only for the preservation of superior cotton itself, but for the assembly of new varieties. Breeding of new varieties requires the availability of germplasm with a wide genetic diversity to be used as a prospective parental cross, a base population with high genetic variation is important breeding material for the assembly of varieties that have the desired traits. High heterozygosity, which means high genetic variation as well, will provide opportunities for improving the genetic quality of populations by exploiting the favorable genes more likely to be present. ${ }^{16}$

\section{Conclusions}

Based on the number of alleles per locus, allele frequencies, and heterozygosity values, it can be concluded that the 12 varieties of cotton in the Kanesia series, including LRA 516, and ISA $205 \mathrm{~A}$, have a fairly high genetic variation.

\section{References}

1. Sudarmadji. Penggunaan benzil amino purine pada pertumbuhan kalus kapas secara in-vitro. Buletin Teknik Pertanian 2003;8:8-11.

2. Sutikno AI. Tanaman kapas dan kaitannya dengan gosipol. Wartazoa 2000;10:7-12.

3. Syakir M. Bibit Unggul \& Pola PIR Mengurai Kemelut Kapas Nasional. Sinar Tani. No. 3337 tahun XL.1-3 2010.

4. Sulistyowati, Sumartini. Kanaesia 10 kanesia 13: empat varietas kapas baru berproduksi tinggi. Jurnal Littri 2009;5:24-32.

5. Powell W, Machary GC, Provan J. Polymorphism revealed by simple sequence repeats. Trends Plant Sci 1996;1:215-22.

6. Iqbal MJ, Aziz N, Seed A, et. al. Genetic diversity evaluation of some elite cotton varieties by RAPD analysis. Theor Appl Genet 1997;94:139-44.

7. Azmat MB, Khan AL. Assesment of genetic diversity among the varieteies of Gossypium arboreum and Gossypium hirsutum through random amplification of polymorphic DNA (RAPD) and simple sequence repeat (SSR) markers. Pak J. Bot 2010;42: 3173-81.

8. Mumtaz AS, Naveed M, Shinwari ZK. Assesment of genetic diversity and germination pattern in selected cotton genotypes of Pakistan. Pak J Bot 2010;42:3949-56.
9. Ali F, Ashraf M, Rehman et al. Development of genetic linkage map of leaf red colour in cotton (Gossypium hirsutum) using DNA markers. Pak J Bot 2009;41:1127-36.

10. Rahman MU, Malik TA, Aslam N, et al. Optimazion of PCR conditions to amplify microsatelite in cotton (Gossypium hirsutum L.) genomic DNA. Int J Agri Biol 2002;4:282-4.

11. Bertini CHCM, Schuster I, Sediyama et al. Characterization and genetic diversity analysis of cotton cultivars using microsatellites. Gen Mol Biol 2006;29: 321-9.

12. Ellegren H. Microsatellites: simple sequences with complex evolution. Genetics 2004;5:435-45.

13. Sumantri C, Farajallah A, Fauzi U, Salamena JF. Keragaman genetik DNA mikrosatelit dan hubungannya dengan performa bobot badan pada domba lokal. Media Peternakan 2008;31:1-13.

14. Sumatri RA, Iskandar DT. Kajian keragaman genetik nyamuk Anopheles barbirostris dan A.vagus di dua daerah endemik penyakit malaria di jawa Barat. Jurnal Matematika dan Saiaans 2005;10:37-44.

15. Rimbawanto A. Pemuliaan Tanaman dan Ketahanan Penyakit pada Sengon. Makalah Disampaikan pada Workshop Penanggulangan Serangan Karat Puru pada Tanaman sengon. Balai Besar Penelitian Bioteknologi dan Pemuliaan Tanaman Hutan. Yogyakarta. 2008.

16. Astirin OP, Sumitro SB. Polimorfisme enzim isositrat dehidrogenase, laktat dehidrogenas and $\alpha$ - glicerofosfat dehidrogenase pada udang windu (Penaeus monodon Fab.) tahan hidrogen sulfida. Biodiversitas 2006;7:2037. 